\title{
Influence of Hayao Miyazaki's Animation on the Cross-Cultural Spread of Japanese Traditional Culture under the Background of 5G and Wireless Communication
}

\author{
Chenmei Li (iD \\ School of Foreign Languages, Guangzhou Huashang College, Guangzhou 511300, China \\ Correspondence should be addressed to Chenmei Li; li_chenmei@outlook.com
}

Received 13 August 2021; Revised 16 September 2021; Accepted 20 September 2021; Published 11 October 2021

Academic Editor: Deepak Gupta

Copyright ( 2021 Chenmei Li. This is an open access article distributed under the Creative Commons Attribution License, which permits unrestricted use, distribution, and reproduction in any medium, provided the original work is properly cited.

\begin{abstract}
The development of $5 \mathrm{G}$ technology has brought tremendous changes to all areas of social life, especially in the external communication of culture; the increasing effect of $5 \mathrm{G}$ technology has become more obvious. All kinds of new media are constantly emerging, and the expression of cultural products is more diversified, and they also have certain characteristics of their own national cultural symbols. As one of the important representatives of Japanese modern and contemporary culture, animation works have made extremely outstanding contributions in promoting the spread of Japanese culture. Japanese animation is not only second to none in Asia but has also many fans all over the world. This article takes the characteristics of Hayao Miyazaki Animation's external communication under the background of 5G as the starting point and deeply analyzes the impact of technological background changes on the external communication of Japanese traditional culture. Through data comparison, it is found that with the support of 5G technology, people's habit of watching videos has changed a lot, from mobile terminals and short videos in the $4 \mathrm{G}$ era to large-screen projections and long animations in the $5 \mathrm{G}$ era. In a certain sense formed the return of the animation viewing form to the television era at the end of the last century. The number of video clicks on major websites shows that the number of Japanese animation products represented by Hayao Miyazaki Animation has increased significantly. Moreover, the age and occupation coverage of the audience is also very wide. The survey shows that people's appreciation of Hayao Miyazaki's animation at this stage is not only the attractiveness of the plot itself, but the deep meaning behind the animation is also the focus of attracting them. This gives Hayao Miyazaki Animation a higher level of appreciation value, that is, guiding countries that have suffered from the side effects of industrial civilization to rethink the relationship between ruleism and development speed. The research results suggest that the development of $5 \mathrm{G}$ technology has given traditional Japanese animation new characteristics in the dissemination of it and directly affected the cross-cultural dissemination effect of Japanese traditional culture. Discover the essence of respecting nature and observing rules in Japanese traditional culture to better serve our social development.
\end{abstract}

\section{Introduction}

The cultural integration between various ethnic groups has shown a trend of more frequent and in-depth development in contemporary times. This trend becomes more rapid with the advent of the $5 \mathrm{G}$ era. When writing literature, writers from various countries will almost deliberately learn from the essence of other cultures. Therefore, how to make better use of the output of cultural products to achieve cultural dissemination, so that the outside world can better understand their own culture, has become the focus of the governments of all countries. The animation industry is one of Japan's important means for foreign cultural exchanges. At the beginning of the 21st century, the Japanese government launched a key training and support plan for cultural products such as animation. After nearly two decades of hard work, Japanese animation has achieved an industry status similar to that of automobiles and electrical appliances.

It can be seen from Table 1 that in the five years from 2013 to 2017, the market share of the Japanese animation industry has achieved rapid growth. Because Japanese animation has absorbed the characteristics of a variety of 
TABle 1: 2013-2017 Japan's animation industry market total market (unit: 100 million yen).

\begin{tabular}{lc}
\hline Year & Total market \\
\hline 2013 & 14709 \\
2014 & 16299 \\
2015 & 18215 \\
2016 & 19924 \\
2017 & 21527 \\
\hline
\end{tabular}

foreign cultures in its creation, the process of appreciating and evaluating it is smoother for the audience. Among the numerous animation works, Hayao Miyazaki's works have always been regarded as classics.

It can be seen from Table 2 that although Hayao Miyazaki's works were mainly created at the turn of the 21st century, which is the early stage of the Japanese government's try hard to cultural strategy, it still has a very strong influence today, and the box office has become insurmountable for the latter. During the peak, his works are not only wellmade but also reflect Japanese traditional culture in different aspects, such as the ubiquitous ruleism in Miyazaki's works and the simple love of the world. When the audience appreciates Hayao Miyazaki's animation works, they can not only bring visual pleasure but also have a certain understanding of Japanese traditional culture. From this perspective, the dissemination of Hayao Miyazaki's animation works represents the Japanese traditional culture to a large extent.

The changes caused by the development of $5 \mathrm{G}$ technology in the field of cross-cultural communication of national cultures have attracted the attention of scholars. Seiple and Hoover pointed out that the cross-cultural dissemination of national culture is a double test of the content and cultural connotation of cultural works, and the dissemination effect reflects which aspect between pluralism and narrow nationalism occupies the active position [1]. Mirzaei Abbasabadi and Soleimani pointed out that with the rapid advancement of communication technology, people have very different ways of contacting other ethnic cultural products, and they have a deeper understanding of the depth of their cultural connotations, which puts forward higher requirements for the quality of cultural products [2]. Yin pointed out that cross-cultural communication ability has a very direct impact on the effect of communication, and the establishment of a scientific evaluation system can effectively improve the quality of cultural exchange products [3]. Chen believes that "cultural discount" is inevitable when all ethnic cultures communicate with each other. Its production is closely related to the quality of cultural products and the compatibility with the own culture of audience, and it is also restricted by the technical level of cultural media. The higher the technical level, the stronger the audience's sense of experience, and the better the effect of cultural exchanges [4]. Duan discussed the contemporary reconstruction of the relationship between cosmopolitanism and nationalism in this field from the perspective of the construction of an ethical system of cross-cultural communication [5]. It is pointed out that the cross-cultural communication of
TABle 2: The top three box office of Hayao Miyazaki's animation works and Douban scores.

\begin{tabular}{lccc}
\hline Anime title & Box office & $\begin{array}{c}\text { Release } \\
\text { year }\end{array}$ & $\begin{array}{c}\text { Douban } \\
\text { score }\end{array}$ \\
\hline $\begin{array}{l}\text { Spirited Away } \\
\text { The Mobile Castle of }\end{array}$ & $\begin{array}{l}30.8 \text { billion yen } \\
\text { Harbin }\end{array}$ & 2001 & 9.4 \\
$\begin{array}{l}\text { Princess Mononoke } \\
19.3 \text { billion yen }\end{array}$ & 2004 & 9.1 \\
\hline
\end{tabular}

national culture should respect the cultural habits of the audience, strengthen communication and exchanges, and enhance the equality of exchanges, so as to achieve the goal of enhancing the value of their own cultural products [6].

\section{Interpretation of Japanese Traditional Cultural Elements in Hayao Miyazaki's Animation}

At the beginning of the twentieth century, a famous French film critic predicted that cartoons would become a symphony of hearts with multiple cultural elements in the future. Seventy years later, Miyazaki made this prediction a reality. In his animation creation, he perfectly integrates visual, auditory, and cultural elements to form a unique and diverse and unified animation style. In his animation works, you can see both the ancient Japanese mythological elements, the quaint buildings with Western style, and the thinking about where humans should go under the invasion of industrial civilization. The reason why Miyazaki Animation can form such a rich connotation is inseparable from the inheritance of Japanese traditional culture [7]. This connection will inevitably be reflected in the content of his animation creation. The name Hayao Miyazaki not only has a pivotal position in the Japanese animation industry but also has a high reputation even in the world. This has made many animation production companies invite him to participate in their own animation production in order to "catch the heat." In order to ensure the scientificity of the research, this article restricts the research objects: specifically referring to the feature-length movies in which Hayao Miyazaki is the director or other important positions alone, which is best known as "Castle in the Sky" and "Spirited Away," ten classic animation works represented by etc.

2.1. Persistence to the Beauty of Things. The sorrow of things is a unique aesthetic consciousness in Japanese traditional culture, and it is an atypical aesthetic experience that arises from the long-term blending of subjectivity and selfdiscipline $[8,9]$. In this kind of culture, "wu sorrow" is not the literal "sorrow of things"; sorrow is a commonly used modal auxiliary word in Japanese, and the beauty of sorrows is the description and transmission of "beauty of objects." It originated in "The Tale of Genji" and has deeply influenced Japanese literature for thousands of years. The expression of this cultural tradition can be seen everywhere in Hayao Miyazaki's animation. 
For example, the animation "Castle in the Sky" shows the unremitting pursuit of the beauty of dreams. The process by which Cedar and Bass look for their dreams is the process by which Hayao Miyazaki externalizes their inner perseverance and perseverance into perceivable beauty. Almost every dream catcher can find his own shadow in this animation. Although the ending may not be satisfactory, this dreamseeking process is also what makes people moving. This makes the whole movie immersed in an aesthetic state. In Nausicaä of the Valley of the Wind, the carrier of grief and beauty presents completely different characteristics. The environment for human existence has been severely damaged due to its own desires, and the ravages of the sea of rot and insects have caused humans to fall into a constant extinction, in an endless loop. And the protagonist Nausicaa is transformed into a "man in blue" who leads mankind to break the game, leading mankind to find hope of survival in the process of growing up.

\subsection{The Pursuit of the Harmonious Unity of Industrial} Civilization and Nature. Although the Japanese government has made a series of wrong decisions on environmental protection at this stage, the country's cultural traditions are striving for the harmonious coexistence of human development and nature. Miyazaki believes that the development of mankind should not be arbitrary from nature but should seek a coexistence node between the two, otherwise it will inevitably encounter natural revenge. For example, in "Nausicaa," Hayao Miyazaki showed the audience a beautiful picture of the harmonious coexistence of man and nature. Huge windmills can be seen everywhere standing in the valley. The highly developed industrial civilization of mankind has been captured by insects and destroyed, and the relatively "primitive" farming civilization has preserved the fire for human survival. The guardians of the forest are docile, but when the forest is damaged, it will immediately burst out with destructive power, so that the groups that destroy nature will receive the punishment they deserve. In "The Valley of Ghosts," this kind of thinking is also more obvious. Ebbsey went to open up the forest for the development of mankind and started a long-term battle with the forest god. In the end, although he defeated the mountain beast god, he was also hit by the latter's dying blow and paid the price of his life. In this cartoon, although Ebbsey appears as a villain, it also represents to a large extent the pioneers who conquered nature under the demands of the development of industrial civilization.

2.3. Devotion to Life and Work. At the same time that Hayao Miyazaki's animation was created, information equipment has been widely used in the animation industry. The animation produced by high-tech means can not only save costs but also upgrade the image quality and production cycle. However, Hayao Miyazaki has always adhered to the traditional animation production method, thinking that only by adhering to the tradition can he better express the creator's ideological characteristics. Therefore, the most important tools for Hayao Miyazaki's animation production are traditional paper and pencils, and information equipment has to be used only when performing postproduction special effects. It is precisely by relying on this "original" production tool that Hayao Miyazaki has beaten European and American high-tech animations at the box office and word of mouth time and time again. For example, "Spirited Away" and "Goldfish Princess on the Cliff" have more than 100,000 drawings. Miyazaki's pursuit of traditional animation production technology is highly compatible with the persistence and dedication of work in traditional Japanese culture.

2.4. Blending of Multiple Cultural Elements. Japanese traditional culture originates from multiple systems, such as Chinese culture and Western culture. This allows Hayao Miyazaki to achieve a perfect combination of multiple cultures in his animation works. His animation works can be said to be based on Japanese traditional culture, supplemented by various cultural system elements. This format not only enhances the appreciability of the work but also expands the audience. What is commendable is that Hayao Miyazaki combines these different styles together, but it is not obtrusive, thus forming a unique Miyaji manga. Looking at Hayao Miyazaki's animation from the perspective of cross-cultural communication, we can find that his works are deeply rooted in Japanese traditional culture and have achieved innovation in expression.

\section{The New Characteristics of Hayao Miyazaki's Animation Cross-Cultural Communication under the Background of 5G}

3.1. It Is Easier to Help the Audience Resonate with the Writer. The development of 5G technology has brought a violent impact on the life that people have become accustomed to, and all industries are on the eve of a comprehensive upgrade. In the $4 \mathrm{G}$ era, mobile phones have replaced traditional televisions and other media as the main medium of cultural consumption. People use smart phones or tablets for much longer than traditional media such as televisions. However, due to the limitations of network transmission rate and cell phone screen size, people seldom appreciate long-form film and television works but prefer fast-paced short videos or film excerpts. In this fragmented appreciation mode, it is difficult for people to think deeply about the cultural meaning behind the video. In the $5 \mathrm{G}$ era, information terminals are more intelligent, and people increasingly prefer large-screen smart devices when they enjoy film and television works $[10,11]$.

As can be seen from Figure 1, in areas where $5 \mathrm{G}$ signals are used, people's mobile phone habits have changed a lot. In the $4 \mathrm{G}$ era, the average daily viewing time of short videos, which occupy the peak of traffic, is gradually shortening, while the viewing time of regular film and television dramas is constantly increasing. More advanced technology and equipment will bring the audience a more comprehensive sensory enjoyment. For example, through smart VR devices, viewers can experience the immersive feeling. Surrounded by beautiful animation scenes, it resonates with Miyaji Animation's love and cherishment of nature $[12,13]$. 


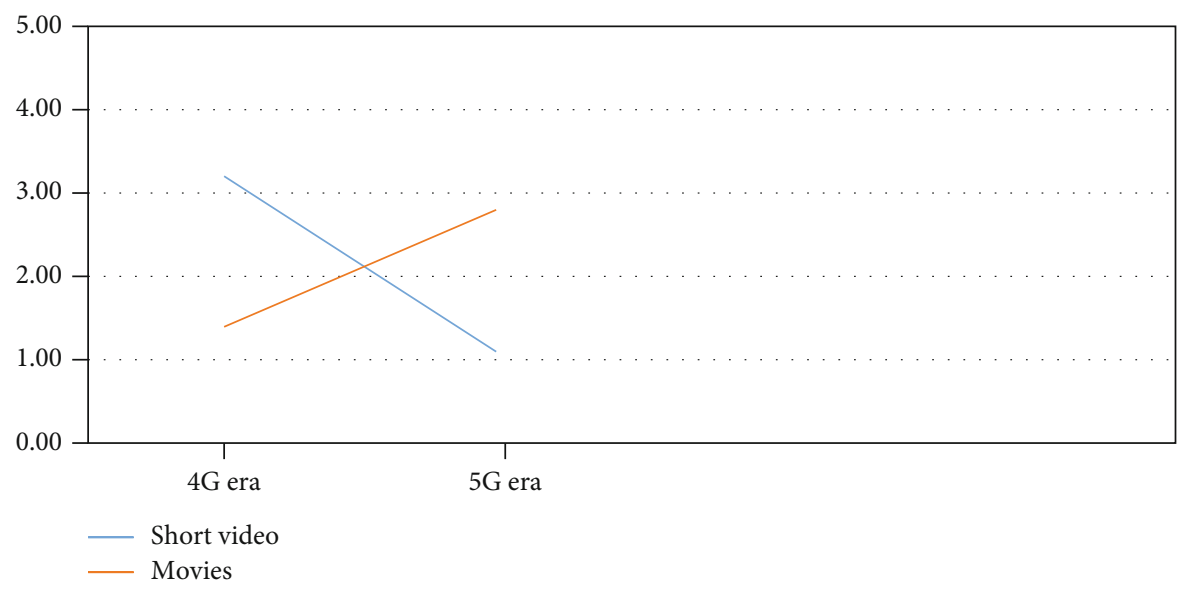

FIGURE 1: Market comparison of content watched by smart devices everyday (unit: hour).

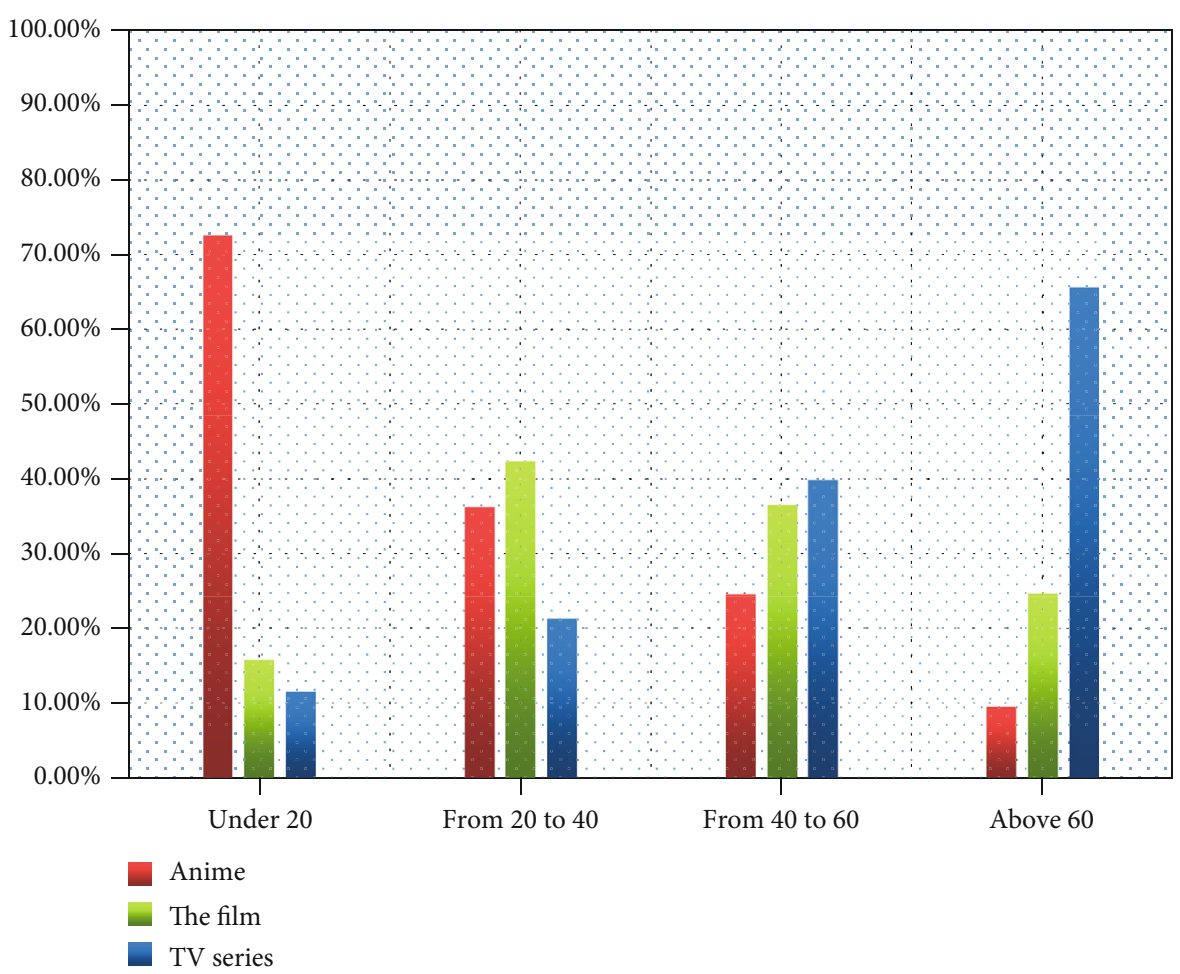

FIGURE 2: Comparison of the market for viewing smart device content by age groups.

3.2. The Change in the Mode of Communication Has Broadened the Scope of the Audience. After the popularization of $5 \mathrm{G}$ equipment, network traffic will inevitably show a spurt of growth. The faster transmission speed of $5 \mathrm{G}$ equipment allows people to watch videos with shorter waiting times and clearer effects. The survey results show that more and more middle-aged people and even the elderly are now using wireless smart terminals to watch video content [14]. When watching animation, Japanese animation is the main focus. Although domestic animation has developed rapidly in recent years, there is still a big gap with Japanese animation in terms of the number of boutiques and the update time. Japanese animation represented by Hayao Gong Miyazaki Animation covers a wide range of ages, which has played a very positive role in the spread of the traditional Japanese culture.

It can be seen from Figure 2 that the audiences of animation at this stage cover almost all age groups. In the past, only teenagers watched animation and the pattern of audiences was further expanded.

3.3. Bringing Greater Challenges to the Cross-Cultural Communication of Japanese Animation. Although Hayao Miyazaki Animation has maintained its high competitiveness for nearly two decades, as the current integration of $5 \mathrm{G}$ technology and animation production has gradually improved, many Internet companies have regard animation production as an important entry point for increasing 
income. Big IP series of animations are constantly being released, such as China's "Nezha: Devil Boy Comes into the World" and "Jiang Ziya" and the United States' "How to Train Your Dragon 3" and "Angry Birds 2," which have caused a lot of problems worldwide and great response. These animations all have outstanding performance in representing their own national culture. The cross-cultural communication of these opponents will inevitably have a great impact on the overseas broadcasting of Hayao Miyazaki Animation. Coupled with Hayao Miyazaki's insistence on hand-made animation, it is difficult to establish a branch plot that conforms to the trend of the times, which will have a certain impact on the interaction between the audience and the animation film, and this impact will inevitably further affect the traditional Japanese culture, cross-cultural communication.

\section{Conclusion}

All in all, in the context of 5G and wireless communication, Japanese traditional culture represented by Hayao Miyazaki Animation has ushered in an excellent opportunity in the process of cross-cultural communication, which has greatly improved the scope of the audience and the depth of cultural communication. But at the same time, the strength of competitors also makes it face greater challenges.

At this stage, my country has entered a period of high production of animation works, and many big IP productions have been released one after another. These characters are beautiful in appearance and exquisite pictures, but they have a high degree of convergence. Almost all of them are adapted from popular online novels, such as "Martial Universe" and "God of War." These animation works are not only in the "shell." Outside of a certain national culture, they are almost all superficial visual works, generally lacking indepth thinking and display of Chinese traditional culture. In the $5 \mathrm{G}$ era, the use of technical means to produce animation is understandable, but works that do not pay attention to cultural connotations cannot become classics that will last forever. If we want to further enhance the cultural temperament of our animation works, we must deeply explore the connotation of traditional culture in the process of animation design and production, realize the fit of animation works and cultural temperament, and reflect cultural reflection. Only in this way can we better arouse the emotional resonance of the audience.

\section{Data Availability}

The datasets used and/or analyzed during the current study are available from the corresponding author on reasonable request.

\section{Conflicts of Interest}

The author declares no competing interests.

\section{Acknowledgments}

Fund projects “Research on Hayao Miyazaki's Animation Works from the Perspective of Traditional Culture Inheritance" were funded by the tutorial system project of Guangzhou Huashang College (Project No. 2020HSDS22).

\section{References}

[1] C. Seiple and D. R. Hoover, "A case for cross-cultural religious literacy," The Review of Faith \& International Affairs, vol. 19, no. 1, pp. 1-13, 2021.

[2] H. Mirzaei Abbasabadi and M. Soleimani, "Examining the effects of digital technology expansion on unemployment: a cross-sectional investigation," Technology in Society, vol. 64, no. 2 , article 101495, 2021.

[3] G. H. Yin, "The cross-cultural development direction of American dramas in China," Media Forum, vol. 4, no. 11, pp. 125126, 2021.

[4] P. Chen, "The historical development and cross-cultural communication of Chinese media in Europe," Overseas Chinese and Chinese History Studies, vol. 2, pp. 14-22, 2021.

[5] L. J. Duan, "The dilemma and optimized path of cross-cultural communication in my country," People's Forum, vol. 14, pp. 98-100, 2021.

[6] L. K. Gong, "Analysis of the cross-cultural communication of internet meme-taking the overseas popularity of "Yijianmei" as an example," Audiovisual, vol. 5, pp. 140-142, 2021.

[7] S. M. Wang and E. L. Du, “"Foreign influencers" short video research from the perspective of cross-cultural communication," China Media Technology, vol. 4, pp. 52-56, 2021.

[8] Y. F. Yang, "An analysis of the cross-cultural communication of TV dramas," Cultural Industry, vol. 10, pp. 63-64, 2021.

[9] J. Chen, "Analysis of cognitive differences in cross-cultural communication of the animation film "Ne Zha"," Media Forum, vol. 4, no. 7, pp. 103-104, 2021.

[10] Z. H. Lv, A. K. Singh, J. H. Li, and H. B. Song, "Deep learning for security problems in $5 \mathrm{G}$ heterogeneous networks," IEEE Network, vol. 35, no. 2, pp. 67-73, 2021.

[11] S. Q. Qu and F. Z. Liu, "National image construction and dissemination in domestic science fiction movies," Science and Technology Think Tank, vol. 5, pp. 41-48, 2021.

[12] J. F. Lin, "Comparison of the narrative characteristics of Chinese and Japanese documentaries from the perspective of cross-cultural communication: taking the traditional cultural documentaries of China Central Television and Japan's NHK Broadcasting Corporation as examples," Putian University Journal, vol. 3, pp. 68-73, 2019.

[13] X. Lan and X. Wang, "Strategies for the integrated development of Chinese martial arts and animation from the perspective of cross-cultural communication," External Communication, vol. 3, pp. 35-37, 2020.

[14] R. Yang, "International expression and meaning sharing in the cross-cultural communication of video games: taking the mobile game "Onmyoji" as an example," Comparative Research on Cultural Innovation, vol. 3, no. 18, pp. 18-20, 2019. 